
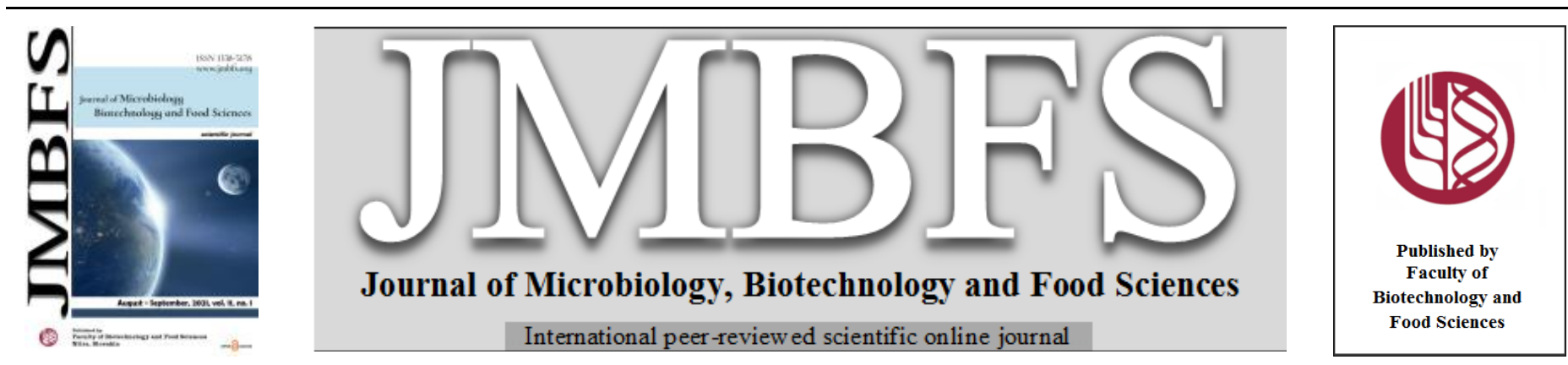

\title{
NEAR INFRARED SPECTROSCOPY MEASUREMENT AND KINETIC MODELING FOR PHYSIOCHEMICAL PROPERTIES OF TABTIM FISH (HYBRID TILAPIA OREOCHROMIS SP.) FILLETS DURING CHILLING STORAGE
}

\author{
Sutee Wangtueai ${ }^{* 1,2}$, Chaluntorn Vichasilp ${ }^{3}$, Tanachai Pankasemsuk ${ }^{4}$, Parichart Theanjumpol ${ }^{4}$, and Yuthana Phimolsiripol ${ }^{1}$
}

\author{
$\operatorname{Address(es):~}$ \\ ${ }^{1}$ Faculty of Agro-Industry, Chiang Mai University, Chiang Mai 50100, Thailand. \\ ${ }^{2}$ College of Maritime Studies and Management, Chiang Mai University, Samut Sakhon, 74000 Thailand. \\ ${ }^{3}$ Faculty of Natural Resources, Rajamangala University of Technology Isan, Sakon Nakhon 47160, Thailand. \\ ${ }^{4}$ Postharvest Technology Research Institute, Chiang Mai University, Chiang Mai 50200, Thailand.
}

*Corresponding author: sutee.w@cmu.ac.th

https://doi.org/10.15414/jmbfs.1412

\section{ARTICLE INFO}

Received 14. 3. 2019

Revised 3. 3. 2021

Accepted 18. 3. 2021

Published 1. 8. 2021

Regular article

open $\mathcal{O}$ access

\begin{abstract}
This research is aimed to investigate the physiochemical properties of Tabtim fish fillets $[\mathrm{pH}$, moisture content, water holding capacity (WHC) and texture profile analysis] during storage at 0,5 , and $10^{\circ} \mathrm{C}$ for up to 18 days. Near infrared spectroscopy (NIR) was used as a nondestructive measurement and kinetics was also applied for determining the quality changes. Results showed that the $\mathrm{pH}$ value increased with an increase of storage time and storage temperature $(\mathrm{P} \leq 0.05)$ while the hardness and WHC were decreased as a result of increasing time and storage temperature $(\mathrm{P} \leq 0.05)$. Change in $\mathrm{pH}$, hardness, gumminess, and chewiness during storage can be described by zero- or first-order reactions. NIR spectra of fish fillets (180 samples) were collected in the reflectance mode with both the shortwavelength region $(700-1000 \mathrm{~nm})$ and long-wavelength region $(1000-2500 \mathrm{~nm})$. A partial regression model with cross validation was created. The models for $\mathrm{pH}$, hardness, adhesiveness, and gumminess demonstrated that the value for the determination coefficient of validation ranged from $0.61-0.73$ while the standard error of prediction was 0.14 for $\mathrm{pH}, 2.58 \mathrm{~N}$ for hardness, $0.21 \mathrm{~N} . \mathrm{mm}$ for adhesiveness, and $1.68 \mathrm{~N}$ for gumminess. The model developed using NIR could predict $\mathrm{pH}$, hardness, adhesiveness, and gumminess as
\end{abstract} basic for a screening test.

Keywords: Near infrared spectroscopy, Chilled fish fillets, Kinetic modeling, Hybrid Tilapia Oreochromis $s p$.

\section{INTRODUCTION}

Fish has higher deterioration after postmortem than terrestrial animals since it has high water activity, neutral $\mathrm{pH}$, and abundant nutrition (Yu et al., 2017). The biochemical and microbial deterioration are the major cause of fish quality losses. Thus the freshness of fish is the most important factor contributing to fishery product qualities from any given species (Zhang et al., 2011). In general, severa techniques can be used in the fish freshness identification such as chemical, biochemical methods, physical methods, microorganism determination, and sensory evaluation (Diop et al., 2016).

The texture of raw flesh fish is an important property of fish quality, which links to consumer acceptability (Wu et al., 2014). Fish myofibril and connective tissue influence texture characteristic of fish meat. Connective tissue has a collagen as a major component related to toughness of flesh while actin and myosin are main components of muscle fiber (Casas et al., 2006). The juiciness and texture of flesh fish depends on water content of fish meat and water holding capacity (WHC) of fish protein. Decrease in WHC is affected to excessive cooking and drip loss (Sikorski, 2002). The water is a main component in muscle which it is an important influence on quality-related parameters of muscle such as appearance, texture and storage stability (Andersen and Jørgensen, 2004). Fish fillets containing high water absorption and moisture has directly impacts sensory acceptability by consumer (Wangtueai and Vichasilp, 2015). Thus, the firmness of fish meat is also determined by determination of moisture content and WHC of the flesh fish. The consumers do not commonly accept the soft mouth feel texture of salmon and this texture also shows a poorer quality of the flesh salmon, which are not suitable for fish industry processing (Ashton et al., 2010; Morkore and Einen, 2003). The measurement of fish texture is considered as a crucial step for fish quality determination in fish industries (Isaksson $\boldsymbol{e t}$ al., 2002). Moreover, it is essential for several factors of fishery industries development such as farming, feeding system, and product management to have higher quality (Veland and Torrissen, 1999).

The measurements of fish texture have two key steps, namely sensory evaluation and texture analysis using texture analyzer (Wu et $\boldsymbol{a l . ,}$ 2014). Finger method is commonly used to assess texture of raw flesh salmon in fish industry (Sigurgisladottir et al., 1999), which are graded by firmness on defined areas on fish muscle. However, the assessors of sensory evaluation must be an expertise or trained panels in order to obtain the accuracy results (Ashton et al., 2010). Although, the measurement using texture analyzer is effective in cost and if the standard of measurement is well controlled, the obtained results can be compared with other results from different testing locations or different times performed measurement (Sigurgisladottir et al., 1999; Ashton et al., 2010). However, the limitation of those measurements in industry cannot be used routinely because the cost and time consuming, many quantities of sample, destructive method, and low efficiency (Wu et al., 2014). Therefore, the practical at industry level needs other alternative methodologies to reduce fish sample using, non-destructive, high efficiency for categorizing of fish quality, and convenience and fast in fish quality assessment.

Near infrared spectroscopy (NIR) is electromagnetic spectrum which corresponds to the wavelength range of $780-2,526 \mathrm{~nm}$. A vibrational spectroscopy employs electron vibrating, leading to absorb and desorb in different energy regarding to chemical compositions. It has special characteristics as the same as the human palm which causes different spectra when analysis with chemometrics, which results more accurate and faster research on types and quantity of constituents in samples. The NIR provides good result for analyzing several of agricultural products. Currently, NIR is a promising technique to monitor product quality parameters. It is accepted as the potential method and offers significant advantages compared to traditional methods such as fast, non-destructive technique, less numbers of testing required, and no sample preparation. NIRs offers solutions on analysing of chemical composition in fish (Masoum et al., 2012; Liu et al., 2015), protein quality and water content in surimi (Uddin $\boldsymbol{e t}$ al., 2006), fat content for several fatty fish (Cozzolino et al., 2002), microbiological change in chilled shrimp during storage with rapidly than the traditional microbiology method (Jiang et al., 2011), lipid characteristics and deterioration of frozen lean fish muscles (Karlsdottir et al., 2014) and also differentiation of fresh and frozen-thawed fish (Uddin et al., 2005; Wang et al., 2018). 
Kinetic modeling is used to predict the reaction or changing in deterioration of fish during clod chain storage. Those prediction models allows companies to optimize their storage management and decreasing of economic losses (Zhang $\boldsymbol{e}$ al., 2011). Recently, some studies have done using models to predict the fish quality changes during storage. The establishment of kinetic models to predict the freshness of fish at different temperatures during storage has been studied such as crucian carp (Yao et al., 2011), grass carp (Zhang et al., 2011). Tsironi et al. (2010) studied the modeling microbial spoilage and quality of gilthead seabream fillets. The raise of total volatile basic nitrogen (TVB-N) and thiobarbituric acidreactive substances (TBARS) model of chilled Tabtim fish fillets was performed by Wangtueai et al. (2016).

Tabtim fish (hybrid Tilapia Oreochromis sp.) or red tilapia is favorite fish for consumer consumption in South-East Asia owing to their white meat, low fat, good taste as well as high nutrition value with having higher omega-3 than other wild freshwater (Likhitrattanapaiboon et al., 2007; Thiansilakul et al., 2010) Tabtim fish products are sold as whole fish or fillets. Chilling storage has been widely used to extend their shelf-life, particularly during transportation and distribution. However, the deterioration of fish quality causes unpleasant appearance and soft texture, which lowers the market value and consumer acceptability. Thus, the present study aimed to apply NIR for determining the physiochemical properties of chilled Tabtim fish fillets stored at different chilling temperatures. The WHC, $\mathrm{pH}$, moisture content, and texture properties were measured by standard method and NIR spectrums including the determination of correlation and accuracy between NIR and standard methods in order to validate the method for product quality control as well as increasing an economic competition in fishery industries.

\section{MATERIALS AND METHODS}

\section{Fish preparation}

The live Tabtim fish (size 500-800 g/fish) were obtained from the farm in Sunpatong district, Chiang Mai, Thailand. Fish were directly transported to the laboratory of Faculty of Agro-industry, Chiang Mai University within $40 \mathrm{~min}$ by providing oxygen. The live fish were stunned in ice with 1:2 ratio of fish per ice and slaughtered by put a sharp knife into gill for bleeding. Then, fishes were scaled, filleted, skinned and washed with cold water twice. Consequently, the individual fish fillets (100-150 g) were selected, drained and packaged into loosefitting zip lock polyethylene bag (Siam Makro Public Co. Ltd., Bangkok, Thailand) with one piece per bag. All stated steps were performed under temperature control $\left(5-10^{\circ} \mathrm{C}\right)$ on ices. All fillets were stored at 0,5 , and $10^{\circ} \mathrm{C}$ for up to18 days in a refrigerator (MIR-55 Sanyo 3, Japan).

\section{Chemical composition and $\mathrm{pH}$ measurement}

Moisture, protein, fat, and ash content were measured according to the method of 934.01, 942.05, 954.01 and 991.36, respectively (AOAC, 2000). The pH measurement was carried out following to the standard AOAC (2000) method. The $5 \mathrm{~g}$ of chopped fish fillets were homogenized with $50 \mathrm{ml}$ of deionize water using homogenizer (T25 digital Ultra Turrax, IKA®-Werke GmbH \& Co. KG, Germany). Then, the $\mathrm{pH}$ of the solutions was measured using a $\mathrm{pH}$ meter $(\mathrm{pH}$ 211, Hanna instruments, Oklahoma, USA), calibrated by buffer, $\mathrm{pH} \mathrm{4,} \mathrm{7,} \mathrm{and} 10$.

\section{Water holding capacity (WHC)}

The WHC was assessed by modified method of Thorarinsdottir et al. (2001) The minced fish $(0.25 \mathrm{~g})$ was placed on Whatman filter paper no. 4 (Whatman Interntional Ltd., Maidstone, England) and wrapped before put into $50 \mathrm{ml}$ centrifuge tubes. The samples were centrifuged with $1,500 \mathrm{rpm}$ at $25^{\circ} \mathrm{C}$ for 15 min. Consequently, the fish samples were removed from the filter paper and this filter paper was weighted before and after centrifuge. The percentage of WHC was calculated as shown in the following equation Eq. 1:

WHC $(\%)=[($ initial fish weight - water in filter paper weight $) /$ initial fish weight $)$ $\times 100] \quad(1)$

\section{Texture analysis}

The texture profile analysis (TPA) was evaluated following the modified method of Wangtueai et al. (2014). The selected parts of the raw fillets (over the central line of the fish fillets) were cut into blocks approximately $30 \times 30 \times 20 \mathrm{~mm}$ using a sharp knife. Texture analyzer TA.XT plus (Stable Micro System Ltd., England) was used for TPA profile. The fish blocks were oriented with the muscle fibers horizontal (height $=20 \mathrm{~mm}$ ) and the blocks were compressed using an $75 \mathrm{~mm}$ diameter of aluminum cylindrical probe until the deformation reached $30 \%$ of the initial height at a pre-test speed $1 \mathrm{~mm} / \mathrm{s}$, test speed $1 \mathrm{~mm} / \mathrm{s}$ and post-test speed 5 $\mathrm{mm} / \mathrm{s}$. Three independent measurements were made for each treatment. TPA profile was performed in term of hardness, cohesiveness, adhesiveness, springiness, gumminess and chewiness.

\section{NIR spectra measurement}

The fish fillets (same sample with physiochemical analysis) were measured NIR spectra using a VIS-NIR (Foss NIRSystems model 6500, Silver Spring, USA) with a standard sample cups. The fillets were cut into a shape of a standard sample cups with $10 \mathrm{~mm}$ of thickness. During measurement, the temperature of fish fillet was controlled at $5-10^{\circ} \mathrm{C}$ by packing in zip-lock polyethylene bag and placed in ice box. The VIS-NIR of 180 samples were measured at reflectance and transmittance mode with short wavelength $(700-1000 \mathrm{~nm})$ and long wavelength $(1000-2500 \mathrm{~nm})$ at room temperature of $25^{\circ} \mathrm{C}$.

\section{Data analysis}

The NIR spectra and physiochemical values were analyzed using Unscramble software (Ver.9.6; CAMO AS, Trondheim, Norway). The spectra treatment method such as smoothing, $2^{\text {nd }}$ derivative, normalization, and multiplicative scatters correction (MSC), and wave length optimization were applied to improve spectral characteristic or reduce noise and baseline shifts from undesirable sources of variation. The partial least square equation (PLS) was created with calibration set and validation set. The statistic values $\left(R^{2}\right.$ and SEP) were calculated to assess the good equation (Karlsdottir et al., 2014; Vichasilp and Kawano, 2015).

\section{Establishment of kinetic models}

Values of the physiochemical properties were plotted vs. time for all temperatures studied and the apparent order of the changing of physiochemical properties $(\mathrm{pH}$, moisture, WHC, hardness, cohesiveness, adhesiveness, springiness, gumminess and chewiness) was determined based on the least square statistical fit. The kinetic reaction of physiochemical properties deterioration was determined as reaction rate constant $(k)$ and regression coefficient $\left(R^{2}\right)$ with zeroorder and first-order reaction (Phimolsiripol et al., 2011). The zero-order (Eq. 2) or first-order (Eq. 3) models were used for describing the degradation of food product quality:

$$
\begin{aligned}
& C=C_{0}-\mathrm{kt} \\
& C=C_{0} \exp (-\mathrm{kt})
\end{aligned}
$$

where $C$ is the measured quality value, $C_{0}$ is the initial quality, $t$ is the storage time (days) and $k$ is the reaction rate constant.

\section{Statistics analysis}

Experiment was run in triplicates. All analyses were run in triplicate from three fillets. Data were subjected to two-ways analysis of variance (ANOVA) and Duncan's multiple-range test (DMRT) was used to compare among means (significance was defined at $\mathrm{P} \leq 0.05$ ) using SPSS 17.0 (SPSS Inc., Chicago, IL, USA).

\section{RESULTS AND DISCUSSION}

\section{Proximate composition of Tabtim fish fillets}

The moisture, protein, lipid, and ash content of Tabtim fish fillets were $78.28 \pm 0.07,18.18 \pm 0.35,2.37 \pm 0.18$ and $1.17 \pm 0.11 \%$, respectively. The result was in accordance with Ungsethaphand $\boldsymbol{e t}$ al. (2010) who reported that Tabtim fish contained $73.89 \pm 0.25 \%$ of moisture, $17.82 \pm 0.21 \%$ of protein, $3.04 \pm 0.14 \%$ of lipid, and $2.76 \pm 0.34 \%$ of ash. Chou and Shiau (1996) also reported proximate composition of Tabtim fish muscle which were $79.50 \%$ of moisture, protein of $12.67 \%, 2.05 \%$ of lipid and $3.89 \%$ of ash content. In addition, The crude protein in Tabtim fish were almost similar amounts with other fresh water fishes such as Nile tilapia, striped catfish, broadhead catfish, snakehead fish, and Thai panga fish, which had 17.29, 14.60, 16.00, 17.50 and 15.21\%. The lipid content of Tabtim fish showed higher value than Nile tilapia $(1.39 \%)$, but lower than Thai panga fish (3.55\%) and broadhead catfish (14.7\%) (Puwastien et al., 1999). The higher lipid content in flesh fish might be caused in a decreasing of quality by lipid oxidation at during storage at low temperature (Zhang et al., 2011).

\section{Physiochemical changes of the Tabtim fish fillet during chilling storage}

The physiochemical changes of the Tabtim fish fillet samples stored in different chilling temperatures during 18 days are shown in Figure 1A-D. The $\mathrm{pH}$ value of fish fillets were increased with storage time (Figure 1A). The results found that temperature and time had significantly effects on $\mathrm{pH}$ value $(\mathrm{P} \leq 0.05)$. At the first storage day, the $\mathrm{pH}$ values of samples stored at 0,5 , and $10^{\circ} \mathrm{C}$ were $6.62,6.60$ and 6.65 , respectively and then slightly increased to $6.92,7.14$ and 7.74 , respectively. The increasing of $\mathrm{pH}$ value can be as the result of volatile bases such as ammonia or trimethylamine, which obtained from protein hydrolysis of fish during spoilage (Ruiz-capillas and Moral, 2001). Additionally, the rate of $\mathrm{pH}$ increase also depends on storage temperature (Sikorski, 1990). 
A

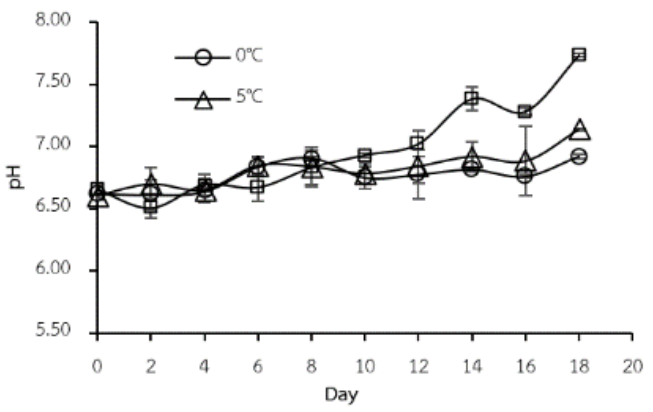

C

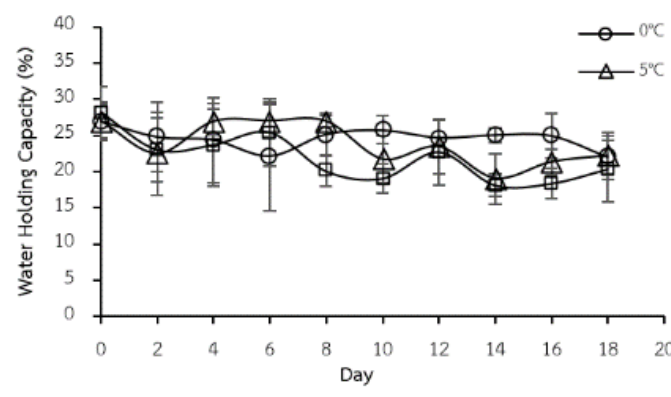

B

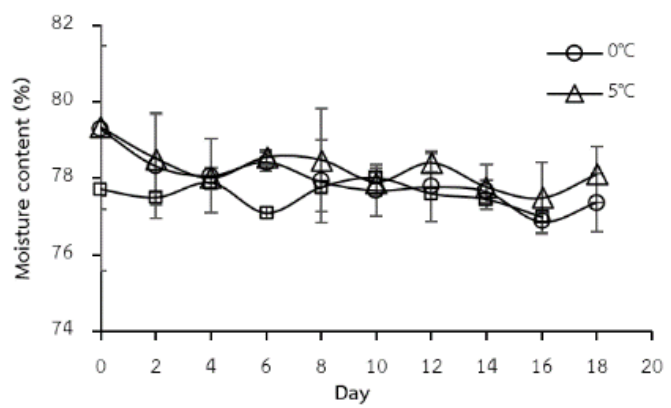

D

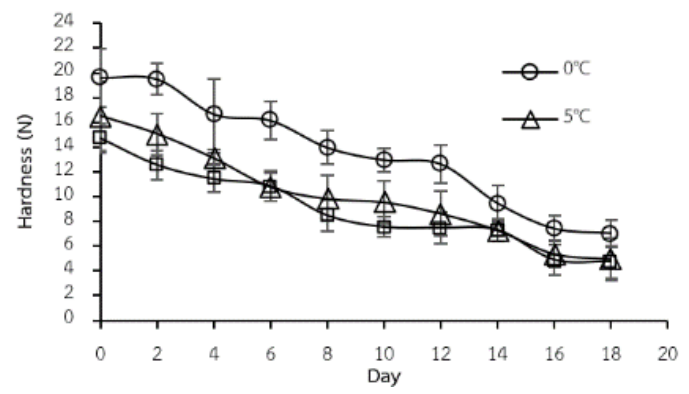

Figure 1 Change of $\mathrm{pH}$, moisture content, water holding capacity (WHC), and hardness of chilled Tabtim fish fillets during chilled storage at 0,5 , and $10^{\circ} \mathrm{C}$ for up to 18 days.

The storage at chilling temperature $\left(0,5\right.$, and $\left.10^{\circ} \mathrm{C}\right)$ up to 18 days, the moisture contents $(\mathrm{MC})$ of fillets had minor gradually decreased $(\mathrm{P} \leq 0.05)$, while the first day of chilling at 0,5 , and $10^{\circ} \mathrm{C}$ were not significantly different in the moisture contents $(\mathrm{P}>0.05)$ with value of $79.28,79.32$ and $78.67 \%$, respectively (Figure 1B). However, $\mathrm{MC}$ of fish fillets stored at 0,5 , and $10^{\circ} \mathrm{C}$ for 18 days showed a non-significant difference $(\mathrm{P}>0.05)$ with representing value at $77.53,77.66$ and 77.54\%, respectively, which was similar to Duan et al. (2010) explaining that no or small changes of water content may be resulted from packing fillets in polyethylene bag tidily, thereby protecting water evaporation from fillets.

The WHC of Tabtim fish fillets stored at 0,5 and $10^{\circ} \mathrm{C}$ were no significantly different $(\mathrm{P}>0.05)$ for each sampling day until 18 days of storage period. However, WHC and hardness of flesh fish was slightly decreased during storage period (Figure 1C and 1D, respectively). This result could be occurred from natural spoilage of fish and it commonly happened in several types of fish during storage (Mohan et al., 2012; Duan et al, 2010; Fan et al., 2009). In addition, the value of texture parameters are shown in Table 1 (hardness, adhesiveness, cohesiveness) and Table 2 (springiness, gumminess, chewiness). These values illustrated significantly different $(\mathrm{P} \leq 0.05)$ on the different sampling days among storage temperature $\left(0,5\right.$, and $\left.10^{\circ} \mathrm{C}\right)$ during the period of 18 days. The hardness, gumminess and chewiness were similar trends with slightly decreased with increasing storage time. Roy et al. (2012) explained that changing of wellhandling fresh fish and kept at relatively low temperature, the degradation of fish texture naturally obtained from a bacterial, enzymatic breakdown, lipid oxidation, and other forms of spoilage.

Table 1 Hardness, adhesiveness, and cohesiveness of chilled Tabtim fish fillets storage at 0,5 and $10^{\circ} \mathrm{C}$ for up to 18 days

\begin{tabular}{|c|c|c|c|c|c|c|c|c|c|}
\hline \multirow[b]{2}{*}{ Day } & \multicolumn{3}{|c|}{ Hardness (N) } & \multicolumn{3}{|c|}{ Adhesiveness } & \multicolumn{3}{|c|}{ Cohesiveness } \\
\hline & $0^{\circ} \mathrm{C}$ & $5^{\circ} \mathrm{C}$ & $10^{\circ} \mathrm{C}$ & $0^{\circ} \mathrm{C}$ & $5^{\circ} \mathrm{C}$ & $10^{\circ} \mathrm{C}$ & $0^{\circ} \mathrm{C}$ & $5^{\circ} \mathrm{C}$ & $10^{\circ} \mathrm{C}$ \\
\hline 0 & $19.62 \pm 2.34^{\mathrm{aA}}$ & $16.50 \pm 2.81^{\mathrm{aB}}$ & $14.73 \pm 1.20^{\mathrm{aB}}$ & $-0.23 \pm 0.25^{\mathrm{abcA}}$ & $-0.22 \pm 0.16^{\mathrm{aA}}$ & $-0.14 \pm 0.08^{\mathrm{aA}}$ & $0.60 \pm 0.02^{\mathrm{aA}}$ & $0.61 \pm 0.04^{\mathrm{aA}}$ & $0.61 \pm 0.05^{\mathrm{aA}}$ \\
\hline 2 & $19.51 \pm 1.26^{\mathrm{aA}}$ & $15.06 \pm 1.68^{\mathrm{aB}}$ & $12.56 \pm 1.19^{\mathrm{bC}}$ & $-0.48 \pm 0.29^{\mathrm{dB}}$ & $-0.26 \pm 0.13^{\mathrm{aAB}}$ & $-0.15 \pm 0.07^{\mathrm{aA}}$ & $0.64 \pm 0.06_{\mathrm{aA}}$ & $0.64 \pm 0.04^{\mathrm{aA}}$ & $0.55 \pm 0.05^{\mathrm{bB}}$ \\
\hline 4 & $16.67 \pm 2.84^{\mathrm{bA}}$ & $13.10 \pm 0.45^{\mathrm{bB}}$ & $11.43 \pm 1.09^{\mathrm{bcB}}$ & $-0.37 \pm 0.23^{\mathrm{cdA}}$ & $-0.24 \pm 0.15^{\mathrm{aA}}$ & $-0.22 \pm 0.13^{\mathrm{aA}}$ & $0.64 \pm 0.05^{\mathrm{aA}}$ & $0.61 \pm 0.04^{\mathrm{aA}}$ & $0.63 \pm 0.05^{\mathrm{aA}}$ \\
\hline 6 & $16.16 \pm 1.53^{\mathrm{bA}}$ & $10.77 \pm 1.10^{\mathrm{cB}}$ & $10.86 \pm 1.21^{\mathrm{cB}}$ & $-0.26 \pm 0.16^{\mathrm{abcdA}}$ & $-0.22 \pm 0.22^{\mathrm{aA}}$ & $-0.54 \pm 0.12^{\mathrm{bB}}$ & $0.64 \pm 0.05^{\mathrm{aA}}$ & $0.61 \pm 0.06^{\mathrm{aA}}$ & $0.63 \pm 0.02^{\mathrm{aA}}$ \\
\hline 8 & $13.97 \pm 1.37^{\mathrm{cA}}$ & $9.83 \pm 1.85^{\mathrm{cB}}$ & $8.46 \pm 1.23^{\mathrm{dB}}$ & $-0.36 \pm 0.15^{\text {bcdA }}$ & $-0.33 \pm 0.28^{\mathrm{aA}}$ & $-0.88 \pm 0.37^{\mathrm{bcB}}$ & $0.64 \pm 0.04^{\mathrm{aA}}$ & $0.64 \pm 0.04^{\mathrm{aA}}$ & $0.65 \pm 0.05^{\mathrm{aA}}$ \\
\hline 10 & $12.97 \pm 0.93^{\mathrm{cA}}$ & $9.55 \pm 1.68^{\mathrm{cdB}}$ & $7.54 \pm 0.82^{\mathrm{dC}}$ & $-0.17 \pm 0.10^{\mathrm{bcA}}$ & $-0.31 \pm 0.26^{\mathrm{aA}}$ & $-1.03 \pm 0.47^{\mathrm{cB}}$ & $0.63 \pm 0.04^{\mathrm{aA}}$ & $0.64 \pm 0.05^{\mathrm{aA}}$ & $0.64 \pm 0.05^{\mathrm{aA}}$ \\
\hline 12 & $12.65 \pm 1.56^{\mathrm{cA}}$ & $8.64 \pm 1.80^{\mathrm{deB}}$ & $7.46 \pm 1.30^{\mathrm{dB}}$ & $-0.18 \pm 0.11^{\mathrm{bcA}}$ & $-0.34 \pm 0.21^{\mathrm{aAB}}$ & $-0.71 \pm 0.60^{\mathrm{abcB}}$ & $0.62 \pm 0.06^{\mathrm{aA}}$ & $0.63 \pm 0.05^{\mathrm{aA}}$ & $0.62 \pm 0.06^{\mathrm{aA}}$ \\
\hline 14 & $9.48 \pm 1.42^{\mathrm{dA}}$ & $7.30 \pm 0.50^{\mathrm{efB}}$ & $7.31 \pm 0.92^{\mathrm{dB}}$ & $-0.12 \pm 0.03^{\mathrm{abA}}$ & $-0.44 \pm 0.33^{\mathrm{aA}}$ & $-1.08 \pm 0.44^{\mathrm{cB}}$ & $0.60 \pm 0.08^{\mathrm{aA}}$ & $0.63 \pm 0.06^{\mathrm{aA}}$ & $0.67 \pm 0.03^{\mathrm{aA}}$ \\
\hline 16 & $7.42 \pm 1.07^{\mathrm{eA}}$ & $5.40 \pm 1.11^{\mathrm{fgB}}$ & $4.88 \pm 1.24^{\mathrm{eB}}$ & $-0.09 \pm 0.10^{\mathrm{aA}}$ & $-0.23 \pm 0.28^{\mathrm{aA}}$ & $-0.93 \pm 0.40^{\mathrm{bcB}}$ & $0.59 \pm 0.05^{\mathrm{aA}}$ & $0.60 \pm 0.06^{\mathrm{aAB}}$ & $0.66 \pm 0.04^{\mathrm{aA}}$ \\
\hline 18 & $7.05 \pm 1.09^{\mathrm{eA}}$ & $4.98 \pm 1.72^{\mathrm{gB}}$ & $4.73 \pm 1.32^{\mathrm{eB}}$ & $-0.19 \pm 0.26^{\mathrm{bcA}}$ & $-0.57 \pm 0.60^{\mathrm{aA}}$ & $-0.80 \pm 0.49^{\mathrm{bcA}}$ & $0.63 \pm 0.06^{\mathrm{aA}}$ & $0.64 \pm 0.07^{\mathrm{aA}}$ & $0.63 \pm 0.06^{\mathrm{aA}}$ \\
\hline
\end{tabular}

Note: Mean \pm SD; different letter ${ }^{\mathrm{A}, \mathrm{B}}$ at the same row are significantly different $(\mathrm{P} \leq 0.05)$ and different letter ${ }^{\mathrm{a}, \mathrm{b}, \mathrm{c}, \mathrm{d}, \mathrm{e}, \mathrm{f}}$ at the same column are significantly different $(\mathrm{P} \leq 0.05)$

Table 2 Springiness, gumminess, and chewiness of chilled Tabtim fish fillets storage at 0,5 and $10^{\circ} \mathrm{C}$ for up to 18 days

\begin{tabular}{|c|c|c|c|c|c|c|c|c|c|}
\hline \multirow{2}{*}{ Day } & \multicolumn{3}{|c|}{ Springiness } & \multicolumn{3}{|c|}{ Gumminess } & \multicolumn{3}{|c|}{ Chewiness } \\
\hline & $0^{\circ} \mathrm{C}$ & $5^{\circ} \mathrm{C}$ & $10^{\circ} \mathrm{C}$ & $0^{\circ} \mathrm{C}$ & $5^{\circ} \mathrm{C}$ & $10^{\circ} \mathrm{C}$ & $0^{\circ} \mathrm{C}$ & $5^{\circ} \mathrm{C}$ & $10^{\circ} \mathrm{C}$ \\
\hline 0 & $65.53 \pm 4.59^{\mathrm{deA}}$ & $63.78 \pm 1.11^{\mathrm{aA}}$ & $64.52 \pm 5.86^{\mathrm{bA}}$ & $11.78 \pm 1.52^{\mathrm{abA}}$ & $10.04 \pm 1.73^{\mathrm{aAB}}$ & $9.00 \pm 1.14^{\mathrm{aB}}$ & $7.77 \pm 1.48^{\mathrm{bcA}}$ & $6.42 \pm 1.22^{\mathrm{abAB}}$ & $5.87 \pm 1.21^{\mathrm{aB}}$ \\
\hline 2 & $77.97 \pm 7.16^{\mathrm{aA}}$ & $71.67 \pm 8.29^{\mathrm{aAB}}$ & $63.52 \pm 3.58^{\mathrm{bB}}$ & $12.54 \pm 1.21^{\mathrm{aA}}$ & $9.63 \pm 1.19^{\mathrm{aB}}$ & $6.87 \pm 1.09^{\mathrm{bC}}$ & $9.83 \pm 1.67^{\mathrm{aA}}$ & $6.97 \pm 1.65^{\mathrm{aB}}$ & $4.35 \pm 0.56^{\mathrm{bcdC}}$ \\
\hline 4 & $75.10 \pm 4.02^{\mathrm{abA}}$ & $69.13 \pm 8.01^{\mathrm{aA}}$ & $69.84 \pm 6.45^{\mathrm{abA}}$ & $10.55 \pm 1.25^{\mathrm{bcA}}$ & $7.99 \pm 0.71^{\mathrm{bB}}$ & $7.10 \pm 0.71^{\mathrm{bB}}$ & $7.95 \pm 1.27^{\mathrm{bA}}$ & $5.57 \pm 1.13^{\mathrm{bcB}}$ & $5.02 \pm 0.80^{\mathrm{abcB}}$ \\
\hline 6 & $74.77 \pm 7.11^{\mathrm{abA}}$ & $67.54 \pm 10.13^{\mathrm{aA}}$ & $71.81 \pm 5.58^{\mathrm{abA}}$ & $10.32 \pm 0.82^{\mathrm{cA}}$ & $6.58 \pm 1.20^{\mathrm{cB}}$ & $6.87 \pm 0.77^{\mathrm{bB}}$ & $7.73 \pm 1.06^{\mathrm{bcA}}$ & $4.47 \pm 1.15^{\mathrm{cdB}}$ & $4.93 \pm 0.61^{\mathrm{abcB}}$ \\
\hline 8 & $71.85 \pm 3.33^{\mathrm{abcd} A \mathrm{~B}}$ & $69.72 \pm 8.95^{\mathrm{aB}}$ & $79.49 \pm 8.66^{\mathrm{aA}}$ & $8.97 \pm 1.11^{\mathrm{dA}}$ & $6.38 \pm 1.50^{\mathrm{cB}}$ & $5.57 \pm 1.05^{\mathrm{bB}}$ & $6.47 \pm 1.07^{\mathrm{cdA}}$ & $4.50 \pm 1.40^{\mathrm{cdB}}$ & $4.48 \pm 1.24^{\mathrm{bdB}}$ \\
\hline 10 & $70.77 \pm 3.88^{\mathrm{bcdA}}$ & $69.17 \pm 6.14^{\mathrm{aA}}$ & $76.76 \pm 9.84^{\mathrm{aA}}$ & $8.11 \pm 0.86^{\mathrm{dA}}$ & $6.12 \pm 1.12^{\mathrm{cB}}$ & $4.80 \pm 0.64^{\mathrm{cB}}$ & $5.76 \pm 0.84^{\mathrm{dA}}$ & $4.23 \pm 0.82^{\mathrm{cdB}}$ & $3.66 \pm 0.45^{\mathrm{dB}}$ \\
\hline 12 & $72.83 \pm 4.41^{\mathrm{abcB}}$ & $65.96 \pm 5.83^{\mathrm{aB}}$ & $78.81 \pm 9.19^{\mathrm{aA}}$ & $7.77 \pm 0.87^{\mathrm{dA}}$ & $5.42 \pm 1.07^{\mathrm{cdB}}$ & $4.64 \pm 0.81^{\mathrm{cC}}$ & $5.67 \pm 0.78^{\mathrm{dA}}$ & $3.61 \pm 0.97^{\mathrm{dB}}$ & $3.71 \pm 0.98^{\mathrm{dB}}$ \\
\hline 14 & $68.62 \pm 6.12^{\text {bcdeB }}$ & $70.00 \pm 4.96^{\mathrm{aB}}$ & $79.30 \pm 9.58^{\mathrm{aA}}$ & $5.73 \pm 1.09^{\mathrm{eA}}$ & $4.59 \pm 0.38^{\mathrm{dB}}$ & $4.88 \pm 0.60^{\mathrm{cB}}$ & $3.96 \pm 1.00^{\mathrm{eA}}$ & $3.22 \pm 0.45^{\mathrm{deB}}$ & $3.86 \pm 0.58^{\mathrm{cdB}}$ \\
\hline 16 & $63.27 \pm 3.47^{\mathrm{eB}}$ & $67.79 \pm 5.93^{\mathrm{aB}}$ & $78.27 \pm 12.91^{\mathrm{aA}}$ & $4.38 \pm 0.87^{\mathrm{fA}}$ & $3.21 \pm 0.46^{\mathrm{eB}}$ & $3.22 \pm 0.78^{\mathrm{dB}}$ & $2.78 \pm 0.59^{\mathrm{eA}}$ & $2.17 \pm 0.34^{\mathrm{eA}}$ & $2.53 \pm 0.75^{\mathrm{eA}}$ \\
\hline 18 & $67.26 \pm 4.88^{\text {bcdeB }}$ & $69.23 \pm 13.14^{\mathrm{aAB}}$ & $81.72 \pm 12.63^{\mathrm{aA}}$ & $4.46 \pm 1.03^{\mathrm{fA}}$ & $3.18 \pm 1.17^{\mathrm{eAB}}$ & $3.01 \pm 0.91^{\mathrm{dB}}$ & $3.03 \pm 0.85^{\mathrm{eA}}$ & $2.25 \pm 1.19^{\mathrm{eA}}$ & $2.51 \pm 0.91^{\mathrm{eA}}$ \\
\hline
\end{tabular}
$(\mathrm{P} \leq 0.05)$ 


\section{Kinetic models}

The experiment data of physiochemical properties changing when storage at 0,5 and $10^{\circ} \mathrm{C}$ were used for determination of kinetic model parameters (Table 3). The regression rate constants $\left(R^{2}\right)$ of $\mathrm{pH}$, hardness, gumminess and chewiness model were appropriated value and indicated the acceptability of the first or zero order reaction in the forecasting those values. However, the adhesiveness, cohesivenes and springiness value showed a lower correlation with storage time at all storage temperatures then those models had low $R^{2}$ in both first and zero order reaction.

Table 3 Reaction rate constants and correlation coefficients of $\mathrm{pH}$, moisture content, water holding capacity (WHC), and texture properties in Tabtim fish fillets during chilling storage at 0,5 and $10^{\circ} \mathrm{C}$

\begin{tabular}{|c|c|c|c|c|c|}
\hline \multirow{2}{*}{$\begin{array}{l}\text { Physiochemical } \\
\text { properties }\end{array}$} & \multirow{2}{*}{$\begin{array}{c}\text { Storage temperature } \\
\left({ }^{\circ} \mathrm{C}\right)\end{array}$} & \multicolumn{2}{|c|}{ zero order reaction } & \multicolumn{2}{|c|}{$1^{\text {st }}$ order reaction } \\
\hline & & $k\left(\right.$ day $\left.^{-1}\right)$ & $R^{2}$ & $k\left(\right.$ day $\left.^{-1}\right)$ & $R^{2}$ \\
\hline \multirow{3}{*}{$\mathrm{pH}$} & 0 & 0.029 & 0.477 & 0.004 & 0.467 \\
\hline & 5 & 0.045 & 0.681 & 0.007 & 0.680 \\
\hline & 10 & 0.120 & 0.914 & 0.017 & 0.917 \\
\hline \multirow{3}{*}{ Moisture } & 0 & -0.192 & 0.572 & -0.002 & 0.574 \\
\hline & 5 & -0.124 & 0.344 & -0.002 & 0.342 \\
\hline & 10 & -0.093 & 0.196 & -0.001 & 0.185 \\
\hline \multirow{3}{*}{ WHC } & 0 & -0.199 & 0.147 & -0.006 & 0.089 \\
\hline & 5 & -0.646 & 0.467 & -0.027 & 0.421 \\
\hline & 10 & -0.847 & 0.522 & -0.037 & 0.500 \\
\hline \multirow{3}{*}{ Hardness } & 0 & -1.487 & 0.934 & -0.119 & 0.925 \\
\hline & 5 & -1.254 & 0.914 & -0.134 & 0.904 \\
\hline & 10 & -1.064 & 0.925 & -0.126 & 0.909 \\
\hline \multirow{3}{*}{ Adhesiveness } & 0 & 0.030 & 0.409 & NA & NA \\
\hline & 5 & -0.026 & 0.258 & NA & NA \\
\hline & 10 & -0.099 & 0.592 & NA & NA \\
\hline \multirow{3}{*}{ Cohesiveness } & 0 & -0.003 & 0.140 & -0.004 & 0.151 \\
\hline & 5 & 0.001 & 0.075 & 0.002 & 0.061 \\
\hline & 10 & 0.007 & 0.366 & 0.011 & 0.363 \\
\hline \multirow{3}{*}{ Springiness } & 0 & -0.768 & 0.345 & -0.011 & 0.341 \\
\hline & 5 & 0.127 & 0.049 & 0.002 & 0.041 \\
\hline & 10 & 1.961 & 0.550 & 0.026 & 0.535 \\
\hline \multirow{3}{*}{ Gumminess } & 0 & -0.943 & 0.922 & -0.124 & 0.898 \\
\hline & 5 & -0.772 & 0.893 & -0.132 & 0.894 \\
\hline & 10 & -0.594 & 0.878 & -0.114 & 0.861 \\
\hline \multirow{3}{*}{ Chewiness } & 0 & -0.720 & 0.856 & -0.135 & 0.853 \\
\hline & 5 & -0.519 & 0.812 & -0.131 & 0.835 \\
\hline & 10 & -0.323 & 0.727 & -0.089 & 0.696 \\
\hline
\end{tabular}

Note: NA: data not available

Spectra of chilled Tabtim fillets, wavelength optimization and spectrum treatments

The original spectra of fillets by VIS-NIR were illustrated in Figure 2, which were measured at absorbance of 700-2500 nm with $2 \mathrm{~nm}$ interval using reflection by NIRSystems model 6500 . The results of the fillet spectra showed different absorbance values due to muscle position in which the fish meats were cut during sample preparation and also the composition of fish muscle, containing different pigments (dark and light) or fat binding of muscles (Karlsdottir et al., 2014; Nilsen et al., 2002). In addition, light scattering affected spectra absorption. It was observed that the differences of spectrum seemed to be increased with an increase of wavelength.

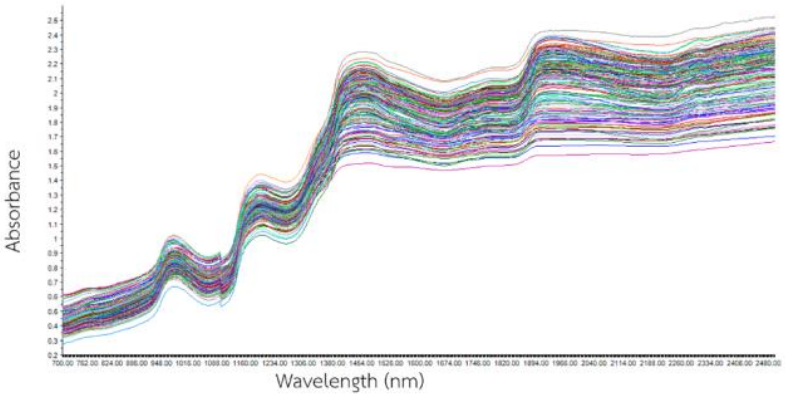

Figure 2 Original NIR spectra of chilled Tabtim fish fillets during chilled storage at 0,5 , and $10^{\circ} \mathrm{C}$ for up to 18 days.

Table 4 Coefficient of calibration $\left(R_{\text {cal }}^{2}\right)$, determination coefficient of validation $\left(R_{\text {val }}^{2}\right)$, and standard error of prediction (SEP) of $\mathrm{pH}$, moisture content, and water holding capacity (WHC), and texture characteristics of chilled Tabtim fish fillets

\begin{tabular}{llll}
\hline Physiochemical properties & $R_{\text {cal }}^{2}$ & $R_{\text {val }}^{2}$ & SEP \\
\hline $\mathrm{pH}$ & 0.68 & 0.73 & 0.14 \\
Moisture content (\%) & 0.49 & 0.54 & 0.71 \\
WHC (\%) & 0.40 & 0.48 & 3.08 \\
Hardness (N) & 0.61 & 0.64 & 2.58 \\
Adhesiveness (N.mm) & 0.48 & 0.61 & 0.21 \\
Springiness (mm) & 0.28 & 0.31 & 6.73 \\
Gumminess (N) & 0.62 & 0.68 & 1.68 \\
Chewiness (N.mm) & 0.35 & 0.40 & 1.58 \\
\hline
\end{tabular}
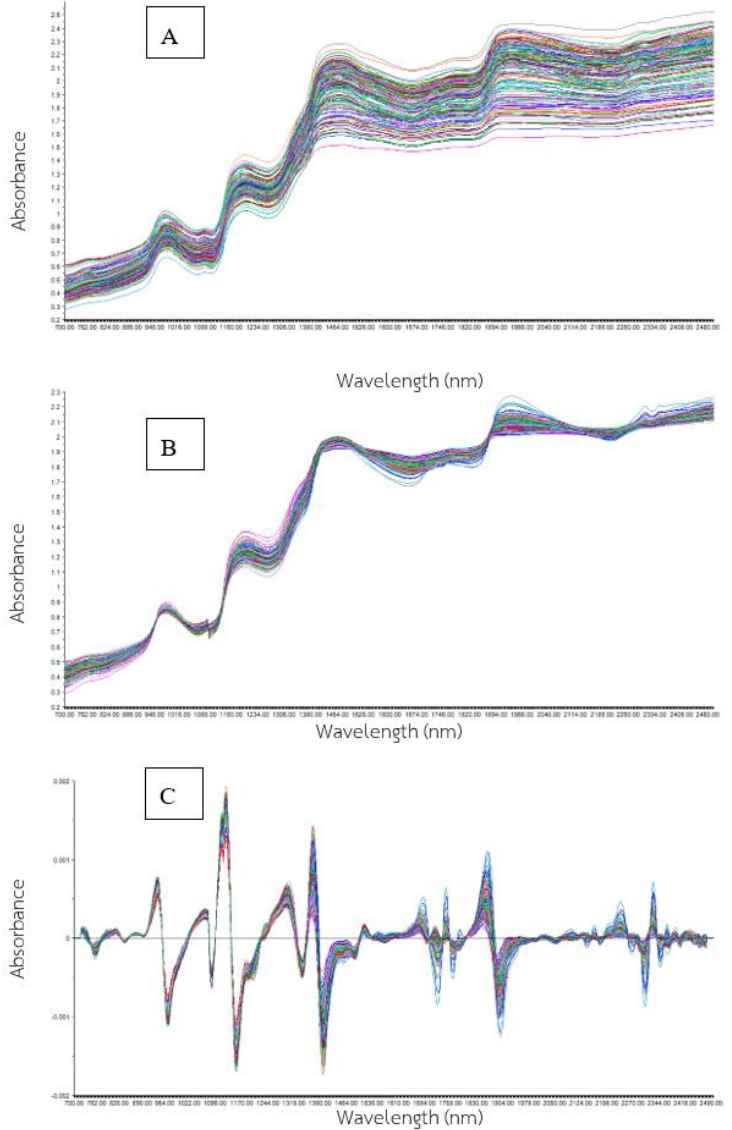

Figure 3 Original NIR spectra treated by the methods of smoothing with 9 points (A), Multiplication scattering correction: MSC (B), and $2^{\text {nd }}$ derivative transformation (C) of chilled Tabtim fish fillets storage at 0,5 and $10^{\circ} \mathrm{C}$ for up to18 days 
The selection of wavelength range or wavelength optimization for the physicochemical values; $\mathrm{pH}, \mathrm{MC}$, WHC, and texture properties (hardness, adhesiveness, cohesiveness, springiness, gumminess and chewiness) was investigated. The wavelength optimization is imperative technique to develop an accurate equation which is a substance-dependent with a specific wavelength The selection of NIRs wavelength could be started by fixed at the lowest wavelength then increased into three ranges i.e. short wavelength $(700-1000 \mathrm{~nm})$, long wavelength $(1000-2500 \mathrm{~nm})$ and the whole ranges $(700-2500 \mathrm{~nm})$ Consequently, chemometrics equation could be calculated by Partial least square regression (PLS) using cross-validation and absorbance of original spectra. The coefficient of calibration $\left(R_{\text {cal }}^{2}\right)$ and standard error of prediction (SEP) was applied to assess the accuracy of the model. Theoretically, the good model (considered an admirable equation) should be a highest of $R_{\text {cal }}^{2}$ and lowest SEP The results showed that the established model of response values were more appropriated creating from a whole wavelength $(700-2500 \mathrm{~nm})$ than long wavelength (1000-2500 nm), which it demonstrated the lowest SEP and the highest $R^{2}$. Therefore, those were suitable for creating a NIRs predicting equation of $\mathrm{pH}, \mathrm{MC}, \mathrm{WHC}$, hardness, adhesiveness, cohesiveness, springiness, gumminess and chewiness by using the whole wavelength from short to long- wavelength $(700-2500 \mathrm{~nm})$. The spectrum analysis showed a different absorbance values that might be a differential of fish muscle positions were measured due to this experiments were used flesh fish sample, which was cut from a whole fish fillet before subject to NIR spectrum measurement. The scattering of fish fillets were also leading to a different spectra because those were different throughout the wavelength range, not specific at wavelength that related with physiochemical values. In addition, a different absorbance values were increased with increasing of wavelength. The spectrum pre-treatment methods are commonly used for noise reduction, baseline correction, resolution enhancement, as well as centering and normalization. A several methods are applied with different propose such as moving average and the Savitzkye-Golay method for noise reduction or Multiplicative Scatter Correction (MSC) for baseline correction (Porep et al., 2015). Williams et al. (1990) reported that uses of $2^{\text {nd }}$ derivative transformation and MSC excluded the sample size problem or scattering. Vichasilp and Kawano (2015) used the technique of smoothing and $2^{\text {nd }}$ derivative transformation for spectra treatments in order to reduce noise and baseline shift which were due to scattering. This study, therefore, investigated chilled fish fillets by using Unscramble program combining with three techniques: Smoothing (Figure 3A), MSC (Figure 3B) and $2^{\text {nd }}$ derivative transformation (Figure $3 \mathrm{C}$ ) to reduce noise and baseline shift from scattering.

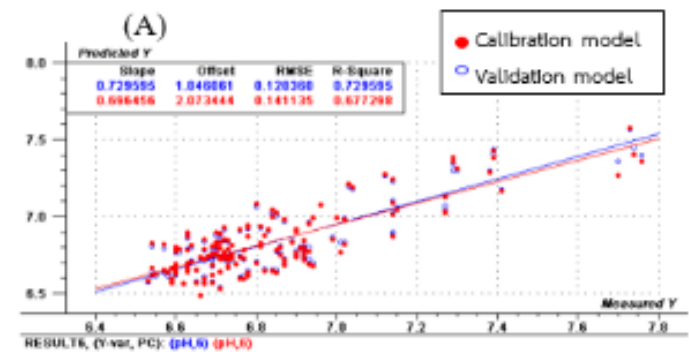

(C)

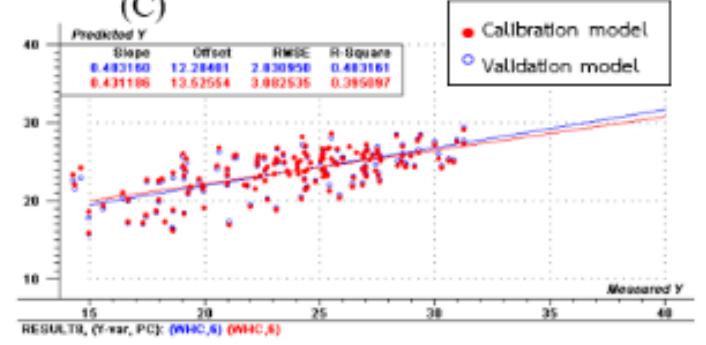

(E)

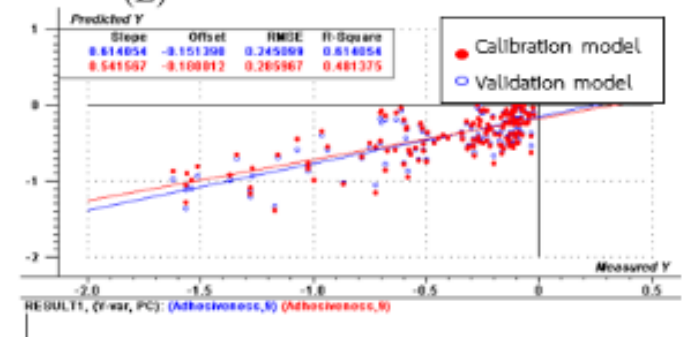

(G)

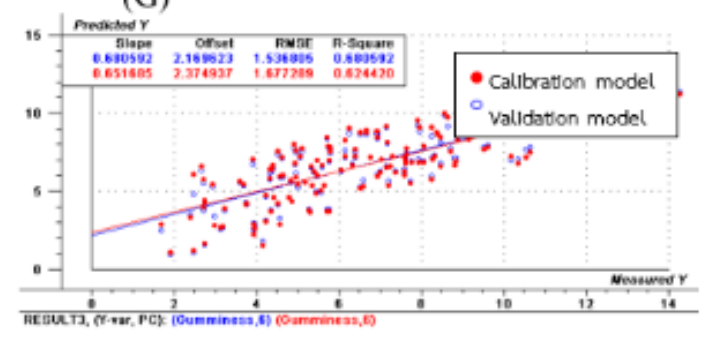

(B)

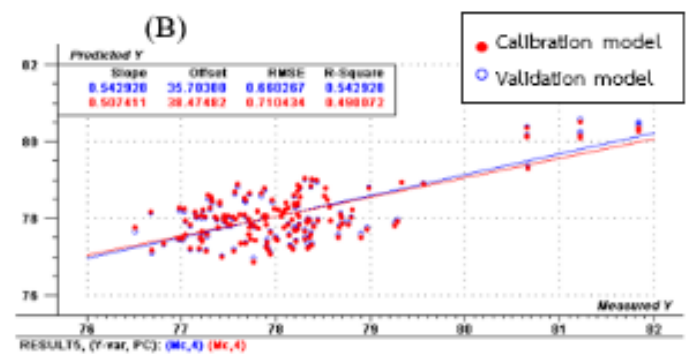

(D)

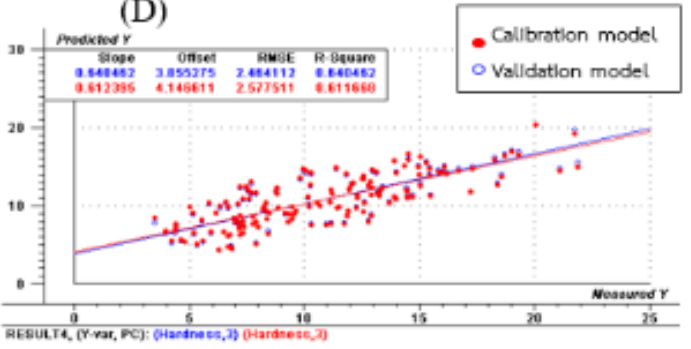

(F)

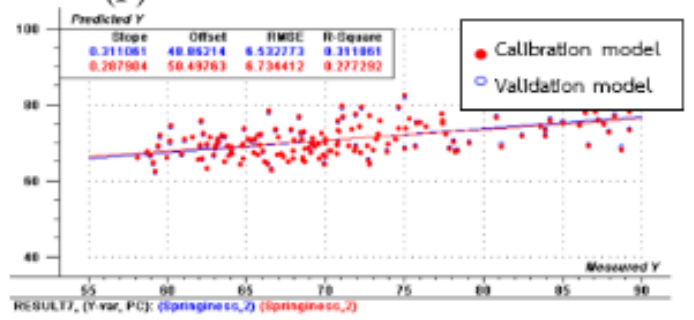

$(\mathrm{H})$

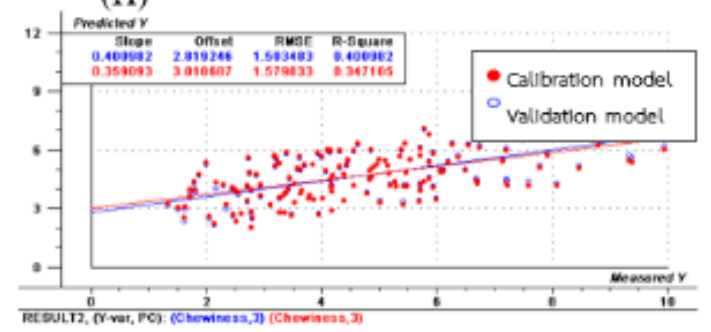

Figure 4 NIRS predicted data against reference data for the $\mathrm{pH}$ (A), moisture content (B), water holding capacity: WHC $(C)$, hardness (D), adhesiveness (E), springiness (F), gumminess $(\mathrm{G})$, and chewiness $(\mathrm{H})$ of chilled Tabtim fish fillets in calibration and validation model.

The spectra treatments can be started with smoothing ( 9 points) for eliminating noise and MSC for reducing sample reflection, followed by the $2^{\text {nd }}$ derivative transformation for separating overlapping peak of spectra in cooperating with smoothing point at 41 points. The techniques of spectra treatments commonly used to reduce reflection in meat products because they had different compositions that caused different reflections. The scatter plots (Figure 4) and regression coefficients of equation (Figure 5) were created from the obtained values from standard method (physical and chemical methods) and predicting values from the model. This value could indicate accuracy of the established model, which should have values locating near trend line, in order to be an 
acceptable model. For the regression coefficients plot, it represented different wavelengths in correlation with the equation obtaining from the established model. When considering several models, it was found that the determination of specific wavelength cloud not be accomplished for each value because of noise in NIRs process. Thus, the physiochemical models could be developed from both short and long- wavelength 700-2500 nm. The coefficient of calibration $\left(R_{\text {cal }}^{2}\right)$ determination coefficient of validation $\left(R_{\text {val }}^{2}\right)$, standard error of prediction (SEP)

(A)

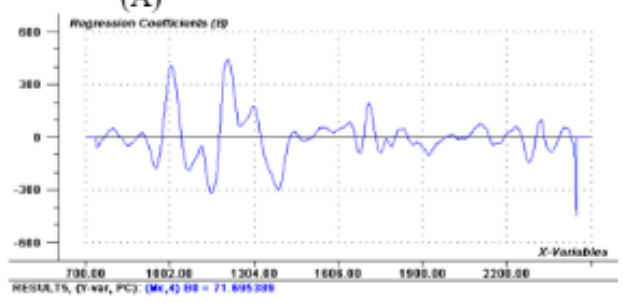

(C)

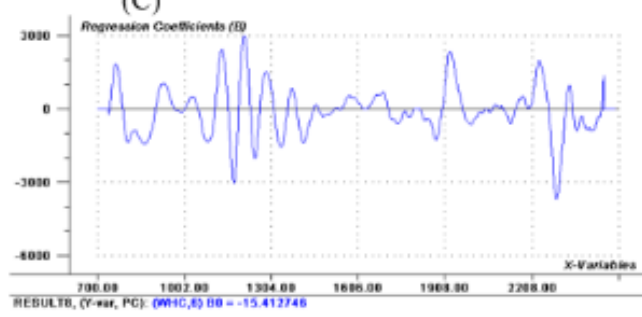

(E)

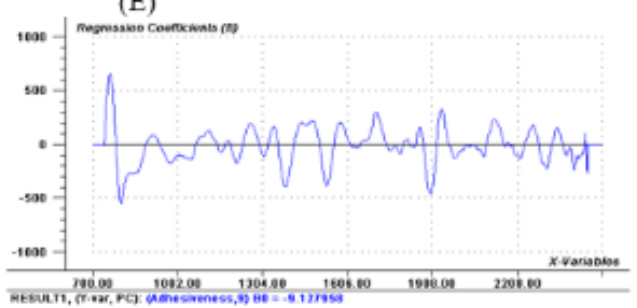

(G)

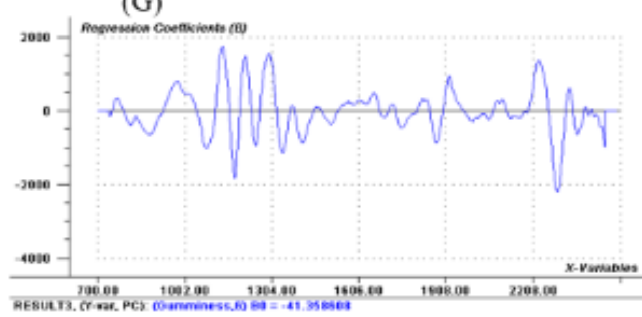

of $\mathrm{pH}$, moisture, WHC, and textures (hardness, adhesiveness, springiness, gumminess and chewiness) are shown in Table 4 . As the results of $R^{2}$ val and SEP, the developed model could be used for screening test of prediction on $\mathrm{pH}$, hardness, adhesiveness, and gumminess. The other values (moisture) such as WHC, springiness and chewiness could also be predicted with lower accuracy due to lower coefficient of validation.

(B)

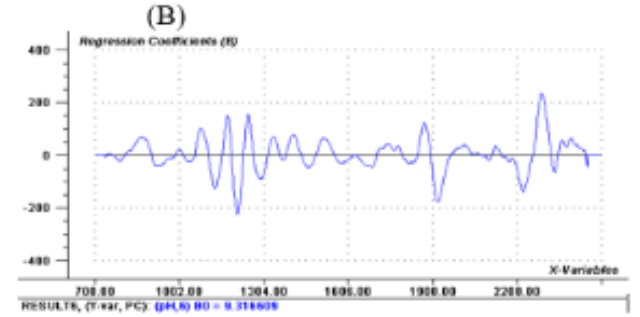

(D)

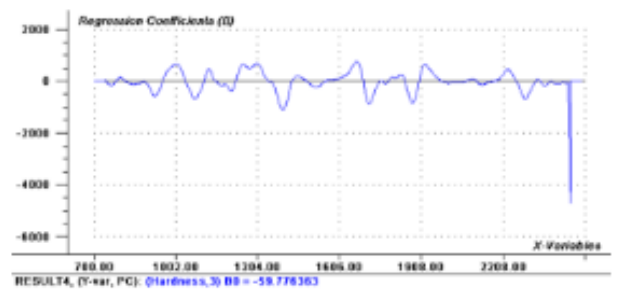

(F)

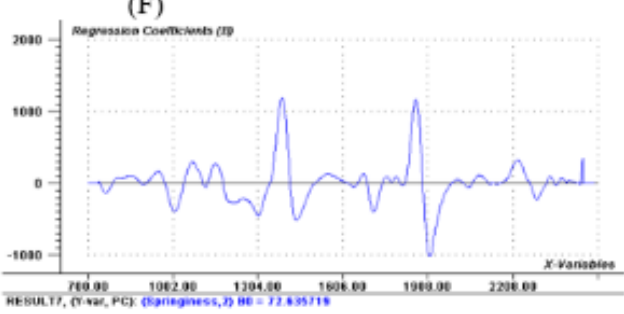

(H)

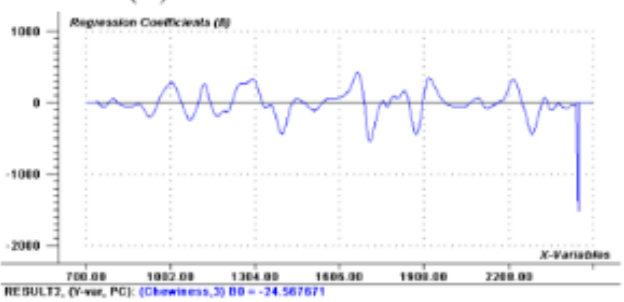

Figure 5 Correlation coefficients between $\mathrm{pH}(\mathrm{A})$, moisture content (B), water holding capacity; WHC (C), hardness $(D)$, adhesiveness $(E)$, springiness $(F)$, gumminess $(G)$, and chewiness $(H)$ and the absorbance data of the average derivative spectra corresponding to the 180 samples

\section{CONCLUSION}

Changes of $\mathrm{pH}$ in chilled Tabtim fish were correlated with increasing of time and storage temperature. The moisture of chilled fish fillets had minor changes during storage. The hardness and WHC were decreased by storage time and temperature changes. In this study, the kinetic analysis of $\mathrm{pH}$, hardness gumminess and chewiness changes in Tabtim fish stored at chilling temperature can be described by zero- or first order reaction. Whereas, MC, WHC, adhesiveness, cohesiveness and springiness had a less correlation with time in all temperatures which showed a lower reaction rate constant in both of zero- and first-order reaction. The application of NIRs for physiochemical changes detection of Tabtim fillets could be used at shot- and long-wavelength (700-2500 $\mathrm{nm})$. The created equation was appropriate for screening test of $\mathrm{pH}$, hardness, adhesiveness, and gumminess prediction. However, the MC, WHC, springiness, and chewiness could be predicted with minor accuracy due to a lower coefficient of calibration. The suggestion for further studies are that all factors causing fresh fish spoilage during sample preparation and NIRs analysis such as light, temperature preparation of fillets, fish muscle position as well as a placing position of fillets into NIRs must be controlled.

Acknowledgement: The authors gratefully acknowledge that this work was financial supported by Chiang Mai University, Thailand.

\section{REFERENCES}

Andersen, C. M. \& Jørgensen, B. M. (2004). On the relation between water pools and water holding capacity in cod muscle. Journal of Aquatic Food Product Technology, 13(1), 13-23. https://doi.org/10.1300/J030v13n01_03.

AOAC. (2000). Official Methods of Analysis of the Association of Official Analytical Chemists $\left(17^{\text {th }}\right.$ Ed.). Washington DC, USA.

Ashton, T. J., Michie, I. \& Johnston, I. A. (2010). A novel tensile test method to assess texture and gaping in salmon fillets. Journal of Food Science, 75(4), S182-S190. https://doi.org/10.1111/j.1750-3841.2010.01586.x.

Casas, C., Martinez, O., Guillen, M. D., Pin, C. \& Salmeron, J. (2006). Textural properties of raw Atlantic salmon (Salmo salar) at three points along the fillet, determined by different methods. Food Control, 17(7), 511-515. https://doi.org/10.1016/j.foodcont.2005.02.013.

Chou, B. S. \& Shiau, S. Y. (1996). Optimal dietary lipid level for growth of juvenile hybrid tilapia, Oreochromis niloticus x Oreochromis aureus Aquaculture, 143, 185-195. https://doi.org/10.1016/0044-8486(96)01266-5.

Cozzolino, D., Murray, I. \& Scaife, J. R. (2002). Near infrared reflectance spectroscopy in the prediction of chemical characteristics of minced raw fish Aquaculture Nutrition, 8, 1-6. https://doi.org/10.1046/j.1365-2095.2002.00176.x. Diop, M., Watier, D., Masson, P. Y., Diouf, A., Amara, R., Grard, T. \& Lencel, P. (2016). Assessment of freshness and freeze-thawing of sea bream fillets (Sparus aurata) by a cytosolic enzyme: Lactate dehydrogenase. Food Chemistry, 210, 428-434. https://doi.org/10.1016/j.foodchem.2016.04.136. 
Duan, J., Cherian, G. \& Zhao, Y. (2010). Quality enhancement in fresh and frozen lingcod (Ophiodon elongated) fillet by employment of fish oil incorporated chitosan coatings. Food Chemistry, 119, 524-532. https://doi.org/10.1016/j.foodchem.2009.06.055.

Fan, W., Sun. J., Chen, Y., Qui, J., Zhang, Y. \& Chi, Y. (2009). Effects of chitosan coating on quality and shelf life of silver carp during frozen storage Food Chemistry, 115, 66-70. https://doi.org/10.1016/j.foodchem.2008.11.060.

Isaksson, T., Swensen, L. P., Taylor, R. G., Fjaera, S. O. \& Skjervold, P. O. (2002). Nondestructive texture analysis of farmed Atlantic salmon using visual/near infrared reflectance spectroscopy. Journal of the Science of Food and Agriculture, 82(1), 53-60. https://doi.org/10.1002/jsfa.997.

Jiang, M., Liu, S.\& Wang, Y. (2011). Effects of antimicrobial coating from catfish skin gelatin on quality and shelf life of fresh white shrimp (Penaeus vannamei). Journal of Food Science, 76(3), M204-209. https://doi.org/10.1111/j.1750-3841.2011.02056.x.

Karlsdottir, M. G., Arason, S., Kristinsson, H. G. \& Sveinsdottir, K. 2014. The application of near infrared spectroscopy to study lipid characteristics and deterioration of frozen lean fish muscles. Food Chemistry, 159, 420-427.

https://doi.org/10.1016/j.foodchem.2014.03.050.

Likhitrattanapaiboon, M., Wilaiphan, P. \& Lawhavinit, O. A. (2007) Contamination of bacteria in chilled fresh Tabtim fish (hybrid tilapia Oreochromis sp.) processing to assess the critical point of processing. Kasetsart Journal (Natural Science), 41, 110-113.

Liu, Y., Ma, D. H., Wang, X. C., Liu, L. P., Fan, Y. X. \& Cao, J. X. (2015) Prediction of chemical composition and geographical origin traceability of Chinese export tilapia fillets products by near infrared reflectance spectroscopy. LWT-Food Science and Technology, 60, 1214-1218. https://doi.org/10.1016/j.lwt.2014.09.009.

Masoum, S., Alishahi, A., Farahmand, H., Maryam, S. \& Nuria, P. (2012) Determination of protein and moisture in fishmeal by near-infrared reflectance spectroscopy and multivariate regression based on partial least squares. Iran Journal of Chemistry and Chemical Engineering, 31, 51-59. https://doi.org/1021 9986/12/3/51.

Mohan, C. O., Ravishankar, C. N., Lalitha, K. V. \& Srinivasa Gopal, T. K (2012). Effects of chitosan edible coating on the quality of double filleted Indian oil sardine (Sardinella longiceps) during chilled storage. Food Hydrocolloids, 26 167-174.https://doi.org/10.1016/j.foodhyd.2011.05.005.

Morkore, T. \& Einen, O. (2003). Relating sensory and instrumental texture analyses of Atlantic salmon. Journal of Food Science, 68(4), 1492-1497. https://doi.org/10.1111/i.1365-2621.2003.tb09672.x.

Nilsen, H., Esaiassen, M., Heia, K. \& Sigernes, F. (2002). Visible/near infrared spectroscopy: a new tool for the evaluation of fish freshness?. Journal of Food Science, 67(5), 1821-1826. https://doi.org/10.1111/j.1365-2621.2002.tb08729.x. Phimolsiripol, Y., Siripatrawan, U. \& Cleland, D. J. (2011). Weight loss of frozen bread dough under isothermal and fluctuating temperature storage conditions. Journal of Food engineering, 106,134-143. https://doi.org/10.1016/j.jfoodeng.2011.04.020.

Porep, J. U., Kammerer, D. R. \& Carle, R. (2015). On-line application of near infrared (NIR) spectroscopy in food production. Trends in Food Science and Technology, 46, 211-230. https://doi.org/10.1016/i.tifs.2015.10.002.

Puwasatien, P., Judprasong, K., Kettwan, E., Vasanachitt, K., Nakngamanong, Y. \& Bhattacharjee, L. (1999). Proximate composition of raw and cooked Tha freshwater and marine fish. Journal of Food Composition and Analysis, 12, 9-16. https://doi.org/10.1006/jfca.1998.0800

Roy, B. C., Ando, M., Itoh, T. \& Tsukamasa, Y. (2012). Structural and ultrastructural changes of full-cycle cultured Pacific bluefin tuna (Thunnus orientalis) muscle slices during chilled storage. Journal of the Science of Food and Agriculture, 92(8), 1755-1764. https://doi.org/10.1002/jsfa.5542.

Ruiz-Capillas, C., Horner, W. A. \& Gillyon, C. M. (2001). Effect of packaging on the spoilage of king scallops (Pecten maximus) during chilled storage. European Food Research and Technology, 213, 95-98. https://doi.org/10.1007/s002170100342.

Sigurgisladottir, S., Hafsteinsson, H., Jonsson, A., Lie, O., Nortvedt, R., Thomassen, M. \& Torrissen, O. (1999). Textural properties of raw salmon fillets as related to sampling method. Journal of Food Science, 64(1), 99-104 https://doi.org/10.1111/j.1365-2621.1999.tb09869.x.

Sikorski, Z. E. (1990). Seafood: Resources Nutritional Composition and Preservation. CRC Press Inc, Florida.

Sikorski, Z. E. (2002). Protein. In Chemical and Functional Properties of Food Components. $2^{\text {nd }}$ Ed. CRC Press Inc, Florida.134-178 pp.

Thiansilakul, Y., Benjakul, S. \& Rechards, M. P. (2010). Changes in heme proteins and lipids associated with off-odour of seabass (Lates calcarifer) and red tilapia (Oreochromis mossambicus $\times$ O. niloticus) during iced storage. Food Chemistry, 121, 1109-1119. https://doi.org/10.1016/j.foodchem.2010.01.058.

Thorarinsdottir, K. A., Arason S., Bogason, S. G. \& Kristbergsson, K. (2001). Effects of phosphate on yield, quality, and water-holding capacity in the processing of salted Cod (Gadus morhua). Journal of Food Science, 66(6), 821826. https://doi.org/10.1111/j.1365-2621.2001.tb15180.x.
Uddin, M., Okazaki, E., Fukushima, H. \& Turza, S. (2006). Nondestructive determination of water and protein in surimi by near-infrared spectroscopy. Food Chemistry, 96, 491-495. https://doi.org/10.1016/j.foodchem.2005.04.017.

Uddin, M., Okazaki, E., Turza, S., Yumiko, Y., Tanaka, M. \& Fukuda, Y. (2005) Non-destructive visible/NIR spectroscopy for differentiation of fresh and frozenthawed fish. Journal of Food Science, 70 (8), C506-C510. https://doi.org/10.1111/j.1365-2621.2005.tb11509.x.

Ungsethaphand, T., Peerapornpisal, Y., Whangchai, N. \& Sardsud, U. (2010) Effect of feeding Spirulina platensis on growth and carcass composition of hybrid red tilapia (Oreochromis mossambicus $\times$ O. niloticus). Maejo International Journal of Science and Technology, 4(2), 331-336.

Veland, J. O. \& Torrissen, O. J. (1999). The texture of Atlantic salmon (Salmo salar) muscle as measured instrumentally using TPA and Warner-Brazler shear test. Journal of the Science of Food and Agriculture, 79(12), 1737-1746. https://doi.org/10.1002/(SICI)1097-0010(199909)79:12<1737::AID-

JSFA432>3.0.CO;2-Y.

Vichasilp, C. \& Kawano, S. (2015). Prediction of starch content in meatballs using near infrared spectroscopy (NIRS). International Food Research Journal, 22, 1501-1506.

Wang, W. L., Chen, W. H., Tian, H. Y. \& Liu, Y. (2018). Detection of frozenthawed cycles for frozen Tilapia (Oreochromis) fillets using near infrared spectroscopy. Journal of Aquatic Food Product Technology, 27(5), 609-618.

https://doi.org/10.1080/10498850.2018.1461156.

Wangtueai, S., Tongsiri, S., Maneerote, J. \& Supaviriyakorn, W. (2014). Effect of phosphate on frozen Nile tilapia fillets. Food and Applied Bioscience Journal, 2(3), 203-215

Wangtueai, S. \& Vichasilp, C. (2015). Optimization of phosphate and salt application to physical and sensory properties of frozen Nile tilapia fillets International Food Research Journal, 22(5), 2002-2009.

Wangtueai, S., Vichasilp, C., Pankasemsuk, T., Theanjumpol, P. \& Phimolsiripol, Y. (2016). Kinetics and nondestructive measurement of total volatile basic nitrogen and thiobarbituric acid-reactive substances in chilled Tabtim fish fillets using near infrared spectroscopy (NIRs). International Journal of Food Engineering, 2(1), 16-20. https://doi.org/10.18178/ijfe.2.1.16-20.

Williams, P. \& Norris, K. (2001). Near-infrared technology in the agricultura and food industries, $2^{\text {nd }}$ Edition, American Association of Cereal Chemists, St. Paul MN, 312 pp.

Wu, D., Sun, D. W. \& He, Y. (2014). Novel non-invasive distribution measurement of texture profile analysis (TPA) in salmon fillet by using visible and near infrared hyperspectral imaging. Food Chemistry, 145, 417-426 https://doi.org/10.1016/j.foodchem.2013.08.063.

Yao, L., Luo, Y., Sun, Y. \& Shen, H. (2015). Establishment of kinetic models based on electrical conductivity and freshness indictors for the forecasting of crucian carp (Carassius carassius) freshness. Journal of Food Engineering, 107 147-151. https://doi.org/10.1016/j.jfoodeng.2011.06.034.

Yu, D., Li, P., Xu, Y., Jiang, Q. \& Xia, W. (2017). Physicochemical, microbiological and sensory attributes of chitosan coated grass carp (Ctenopharyngodon idellus) fillets stored at $4^{\circ}$ C.International Journal of Food Properties, 20, S202-S213. https://doi.org/10.1080/10942912.2016.1163267.

Zhang, L., Li, X., Lu, W., Shen, H. \& Luo, Y. (2011). Quality predictive models of grass carp (Ctenopharyngodon idellus) at different temperatures during storage. Food Control, $22, \quad 1197-1202$ https://dx.doi.org/10.1016/j.foodcont.2011.01.017. 